\title{
PEMBUATAN PUPUK ORGANIK PADAT DARI AMPAS BIOGAS (BIO-SLURRY) KOTORAN SAPI DI DESA PERESAK KABUPATEN LOMBOK BARAT
}

\author{
Muanah $^{1 *}$, Karyanik ${ }^{2}$, Muliatiningsih ${ }^{3}$, Suwati $^{4}$, Earlyna Sinthia Dewi ${ }^{5}$ \\ 1*, 2, 3, 4 Program Studi Teknik Pertanian, Fakultas Pertanian, Universitas Muhammadiyah Mataram \\ ${ }^{5}$ Program Studi Teknologi Hasil Pertanian, Fakultas Pertanian, Universitas Muhammadiyah Mataram \\ Corresponding author : \\ E-mail: muanahtp@gmail.com
}

\section{Diterima 13 November 2019, Disetujui 19 November 2019}

\begin{abstract}
ABSTRAK
Salah satu faktor yang mempengaruhi keberhasilan masyarakat dalam bertani adalah kecukupan pupuk dalam pemeliharaan. Melihat fenomena yang terjadi beberap dekade ini masyarakat sering mengalami gagal panen disebabkan langkanya ketersediaan pupuk, sehingga menyebabkab masa pemupukan tertunda. Maka dari itu, kegiatan ini bertujuan untuk memberikan penyuluhan dan pelatihan kepada masyarakat desa Peresak untuk mengolah ampas biogas (Bio-Slurry) kotoran sapi menjadi pupuk organik padat. Kegiatan pendampingan ini dilakukan supaya masyarakat mampu mengahasilkan pupuk organik dengan kandungan hara yang tinggi. Selain itu, hasil yang diharapkan dari pupuk organik bioslurry ini dapat mengurangi ketergantungan masyarakat terhadap penggunaan pupuk kimia, karena pupuk organik yang dihasilkan sudah mencukupi nutrisi yang dibutuhkan oleh tanaman dan dapat memperbaiki kondisi tanah secara perlahan serta dapat menekan biaya produksi.
\end{abstract}

Kata kunci: Kotoran sapi, bio-slurry, pupuk organik, nutrisi.

\section{ABSTRACT}

One of the factors affecting the success of the community in farming is the adequacy of fertilizer in the maintenance. Seeing the phenomenon that occurs several decades the community often experienced crop failure due to the scarred availability of fertilizer, so that the fertilization period is delayed. Therefore, this activity aims to provide counseling and training to the community of Peresak village to process biogas pulp (Bio-Slurry) of cow manure into solid organic fertilizer. This mentoring activity is done so that people are able to reduce organic fertilizer with high nutrient content. In addition, the expected result of bio-slurry organic fertilizer can reduce public dependence on the use of chemical fertilizers, because the resulting organic fertilizer is sufficient nutrients needed by plants and can improve soil conditions and can reduce production costs.

Keywords: Cow manure, bio-slurry, organic fertilizer, nutrients.

\section{PENDAHULUAN}

Desa Peresak merupakan salah satu desa yang ada di kecamatan Narmada Kabupaten Lombok Barat. Berdasarkan informasi yang disampaikan oleh kepala dusun Tebao desa Peresak bahwa sebagian besar masyarakat bekerja sebagai petani dan peternak. Adapun jenis ternak yang dipelihara adalah jenis sapi. Masing-masing kepala rumah tangga memiliki 2 sampai 3 ekor sapi. Berdasarkan kondisi tersebut oleh Tim biogas rumah (BIRU) menjadikan desa Peresak salah satu sasaran utama pembangunan instalasi biogas berbahan baku kotoran sapi. Adanya program ini masyarakat tidak bergantung lagi dengan gas LPG, karena jumlah gas yang dihasilkan sudah cukup untuk kebutuhan memasak setiap harinya.
Jumlah instalasi biogas yang dibangun di desa Perasak sejak tahun 2014 hingga 2015 sebanyak 50 unit dengan skala rumah tangga berukuran $4 \mathrm{~m}^{3}$. Tujuan dari pembuatan skala rumah tangga adalah disesuaikan dengan pemenuhan bahan yaitu cukup dengan dua ekor sapi saja (Biogas Rumah, 2014).

Limbah kotoran sapi memiliki potensi yang tinggi untuk dijadikan sebagai bahan utama pembuatan biogas. Kandungan gasnya yang tinggi apabila tidak dikelola dengan baik dapat mencemari lingkungan seperti menimbulkan bau dan penyakit bagi pemilik ternak serta lingkungan sekitar. Jumlah kotoran yang dihasilkan setiap hari sebesar $23,59 \mathrm{~kg}$ untuk satu sapi dewasa.

Beberapa jenis gas yang terkandung seperti Amonia dan hidrogen sulfida serta sejumlah besar gugusan organik lainnya 
merupakan hasil dekomposisi biologis dari bahan organik pada kotoran ternak. Apabila gas semacam itu terhirup dalam konsentrasi tinggi, maka dapat menyebabkan kematian pada manusia (Saputro, 2014).

Biogas adalah suatu gas yang mudah terbakar yang dapat dihasilkan dari kotoran sapi. Adapun kandungan biogas yang dihasilkan terdiri dari gas metana $\left(\mathrm{CH}_{4}\right)$, Karbon Dioksida $\left(\mathrm{CO}_{2}\right)$, Hidrogen Sulfida $\left(\mathrm{H}_{2} \mathrm{~S}\right)$ dan Amoniak $\left(\mathrm{NH}_{3}\right)$. Untuk mendapatakan gas tersebut diperlukan instalasi yang dikenal dengan bio digester (Depdagri, 2008). Jenis bio digester yang dibuat pada lokasi pengabdian adalah tipe kubah (fixed done.) Tipe ini hampir seluruhnya terbuat dari batu bata dan ditanam dalam tanah. Keuntungan dari model ini adalah biaya lebih yang dikelukan lebih murah dan mampu bertahan selama 20-25 tahun, namun kelemahannya pemilik instalasi sulit untuk membersihkan kotoran atau kerak dalam reaktor.

Dalam pembuatan biogas, kotoran sapi dicampur air dengan porsi 1:1, artinya $1 \mathrm{~kg}$ kotoran sapi dicampur dengan 1 liter air diaduk merata. Selanjutnya campuran bahan ini dimasukkan dalam bio reaktor untuk difermentasi. Tujuan fermentasi adalah memisahkan biogas dalam kotoran sapi. Pembentukan ini terjadi selama kurang lebih 50 hari. Biogas yang dihasilkan akan menguap dan tertampung dalam kubah sebelum dialirkan atau digunakan, sedangkan ampasnya keluar melalui oulet yang sudah disediakan tanpa berkurang sedikitpun.

Limbah atau ampas biogas yang dihasilkan ini disebut dengan Bio-slurry. Bioslurry memiliki potensi yang sangat baik untuk dijadikan sebagai pupuk organik padat. Kandungan nutrisi ini sangat penting untuk pertumbuhan tanaman. Kandungan unsur makro yang dibutuhkan tanaman dalam jumlah besar antara lain Nitrogen $(\mathrm{N})$, Phospor $(\mathrm{P})$, Kalium (K), Kalsium (Ca), Magnesium (Mg), dan Sulfur (S). Serta nutrisi mikro yang diperlukan dalam jumlah sedikit seperti Besi (Fe), Mangan $(\mathrm{Mn})$, Tembaga $(\mathrm{Cu})$, dan Seng $(\mathrm{Zn})$ (Biogas Rumah, 2014).

Selain kaya bahan organik bernutrisi lengkap, bio-slurry juga mengandung mikroba probiotik yang membantu menyuburkan lahan serta mengendalikan penyakit pada tanah. Dampaknya tentu tanah akan menjadi lebih subur dan sehat sehingga produksi meningkat. Adapun mikoba ynag terkandung dalam bioslurry antara lain 1) mikroba selulitik yang bermanfaat untuk pengomposan, (2) mikroba penambat nitrogen yang bermanfaat untuk menangkap dan menyediakan nitrogen, (3) mikroba pelarut Phospat yang bermanfaat melarutkan dan menyediakan Phospor yang siap serap, dan (4) mikroba Lactobacillius sp yang berperan dalam mengendalikan serangan penyakit tular tanah.

Melihat fenomena yang terjadi pada masyarakat yang tinggal didesa Peresak saat ini sangat perlu dilakukan penyuluhan dan pelatihan. Berdasarkan survey awal kegiatan ini sudah mendapatkan sambutan yang baik dari masyarakat dan karena ketidaktahuan masyarakat akan manfaat dari Bio-Slurry tersebut, serta bapak-bapak dan ibu-ibu belum mengetahui cara pengolahan Bio-Slurry yang baik, sehingga dalam pengabdian ini penyuluh atau Dosen berbagi ilmu untuk memberikan penjelasan dan pelatihan kepada masyarakat dengan tema "pengolahan ampas biogas menjadi pupuk organik padat". Tujuan dari pendampingan ini bahwa pupuk yang dihasilkan dapat mengurangi kebutuhan penggunaan pupuk kimia, sehingga biaya yang dikeluarkan untuk pembelian pupuk juga secara tidak langsung berkurang.

Disamping dapat menyediakan kebutuhan pupuk sendiri juga dapat dijual. Usaha dari penjualan akan memberikan keuntungan yang sangat menjanjikan. Disisi lain juga kami menawarkan kepada petani untuk melakukan kerjasama dalam penjualan atau pendistribusian pupuk sehingga pupuk organik bio-slurry yang dihasilkan lebih dikenal oleh masyarakat umum.

\section{METODE}

Pengabdian ini dilaksanakan pada hari Kamis, tanggal 19 September 2019, Tepatnya di Dusun Tebao desa Peresak Kecamatan Narmada Kabupaten Lombok barat.

Metode pengabdian yang digunakan dalam kegiatan ini adalah penyuluhan dan pelatihan. Penyuluhan dilakukan pada tahap awal untuk penyampaian secara teori terkait manfaat dan cara pengolahan bio-slurry baik. Setelah itu dihari yang sama dilakukan pelatihan pengolahan bio-slurry menjadi pupuk organik padat dengan di dampingi oleh Dosen atau Tim penyuluh Fakultas Pertanian Ummat.

Adapun bahan yang digunakan adalah, bio-slurry padat yang sudah tertampung. Sedangkan alat yang digunakan antara lain sekop/cangkul, terpal/karung saringan besi dan plastik/karung.

\section{HASIL DAN PEMBAHASAN Kegiatan Penyuluhan}

Peserta kegiatan penyuluhan dihadiri oleh 34 orang merupakan warga yang tinggal di sekitar dusun Tebao desa peresak Kecamatan Narmada Kabupaten Lombok Barat. Dimana peserta yang hadir ini diprioritaskan untuk 
masyarakat yang sudah memiliki instalasi biogas, sehingga setelah dilakukan kegiatan ini masyarakat memiiki bekal untuk melakukan pengolahan bio-slurry secara mandiri.

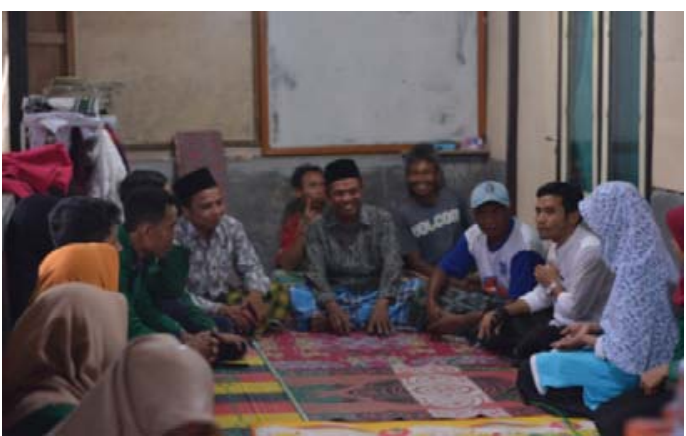

Gambar 1. Penyuluhan pengolahan Bio-slurry

\section{Kegiatan Pelatihan}

Kegiatan pelatihan dilakukan untuk memperaktikan secara langsung teori yang sudah disampaikan pada tahap penyuluhan. Kegiatan ini dilakukan oleh masyarakat dengan didampingi oleh Dosen/Tim penyuluhan Fakultas Pertanian Universitas Muhammadiyah Mataram. Berikut adalah tahapan-tahapan yang dilakukan, yaitu tahap (1) Pengumpulan Bio-slurry, bio-slurry bio-slurry yang keluar dari bio reaktor secara bertahap maka langkah awal yang dilakukan adalah masyarakat tidak lagi membuang ampas biogas tersebut ke tempat pembuangan sampah, melainkan ditampang selama \pm satu minggu baru ke tahap berikutnya.

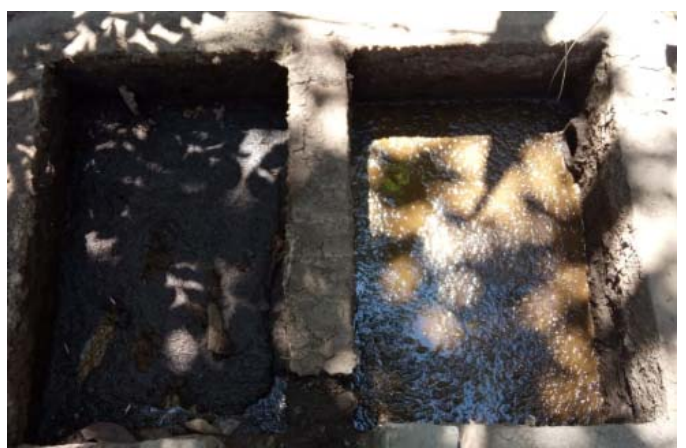

Gambar 2. Penampungan Bio-Slurry

Tahap (2) Pemindahan Bioslury, Bio-slurry padat yang sudah tertampung selanjutnya dipindahkan pada tempat yang sudah disediakan dengan beralaskan terpal atau karung serta memiliki naungan. Tujuan pemberian naungan adalah untuk menghindari bio-slurry dari sinar matahari langsung, karena pengeringan langsung dibawah terik matahari akan mempengaruhi kualitas pupuk yang dihasilkan. Naungan yang digunakan beragam ada yang menggunakan naungan permanen seperti genteng, daun kelapa dan terpal.

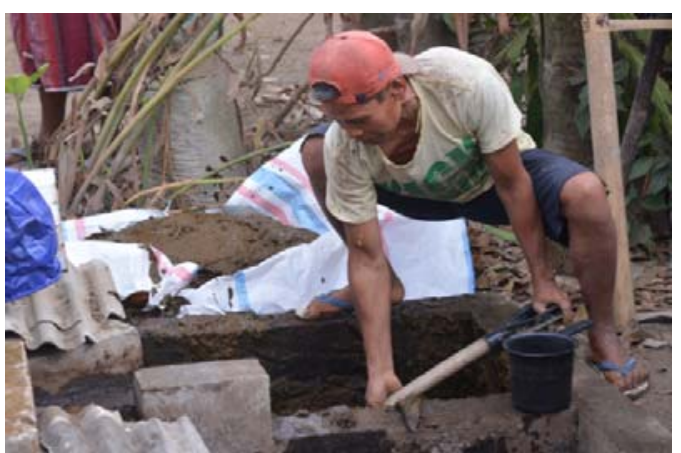

Gambar 3. Pemindahan Bio-Slurry

Tahap (3) dikering anginkan, pada tahap ini selain ternaungi agar terhindar dari terik matahari, juga dilakukan rotasi atau pembalikan 1-2 kali perminggu. Pengringan dilakukan selama kurang lebih 40 hari, setelah itu dilakukan penyaringan untuk mendapatkan ukuran atau struktur pupuk yang seragam.

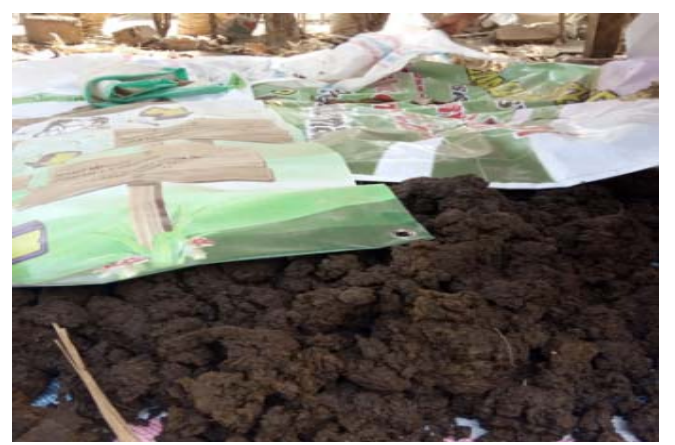

Gambar 4. Proses pengeringan bio-slurry

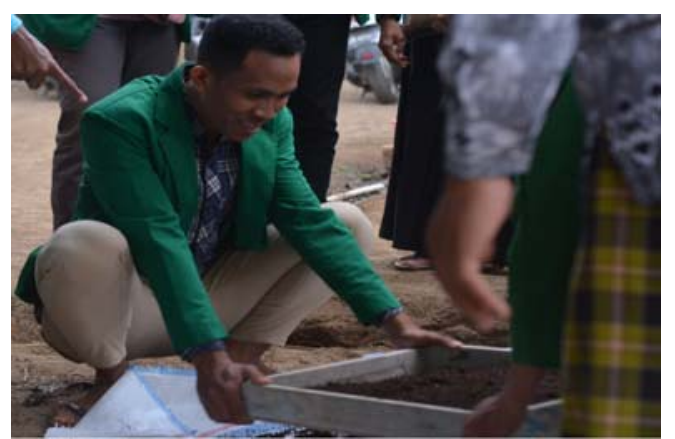

Gambar 5. Penyaringan pupuk organik bioslurry

Tahap (4) Pengemasan, pengemasan pupuk bio-slurry padat yang dihasilkan menggunakan karung untuk ukuran $50 \mathrm{~kg}$, sedangkan kemasan yang menggunakan plastik ukuran untuk $10 \mathrm{~kg}$ dan $3 \mathrm{~kg}$. Adapun tujuan dilakukan pengemasan ini adalah untuk memudahkan proses pengangkutan atau transportasi ketempat pengaplikasian/kesawah serta untuk pemasaran pada beberapa centra penanaman yang ada di desa Peresak Kabupaten Lombok Barat. 


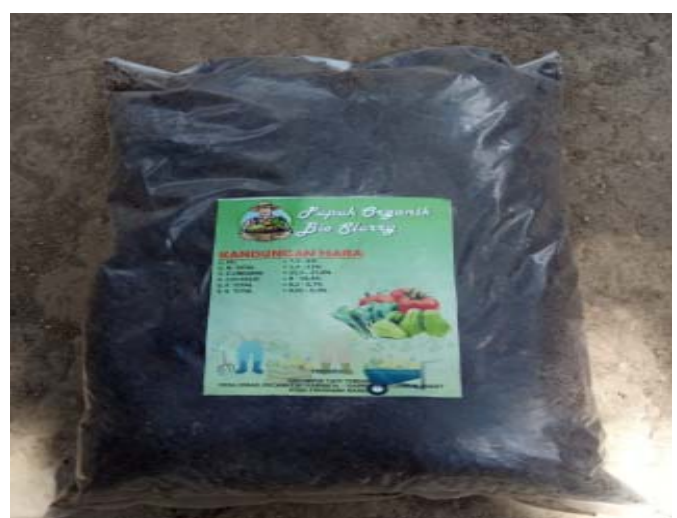

Gambar 6. Pupuk organik bio-slurry
Ternak Patra Sutera. Rekayasa Vo. 12. No. 2,Desember 2014.

\section{SIMPULAN DAN SARAN \\ Simpulan}

Berdasarkan hasil kegiatan pengabdian yang dilakukan, dapat ditarik kesmpulan sebagai beriku :

1. Kegiatan pengabdian yang dilakukan di desa Peresak berjalan lancar, hal ini terlihat dari antusias masyarakat dalam penyuluhan dan pelatihan.

2. Setelah dilakukan kegiatan pengabdian ini, masyarakat memiliki pengetahuan dan kemampuan dalam mengolah limbah biogas menjadi pupuk organik padat.

3. Produk hasil pengabdian dapat mengurangi ketergantungan masyarakat dalam penggunaan pupuk kimia.

\section{Saran}

Adapun saran yang perlu disampaikan setelah dilakukan kegiatan pengabdian ini adalah sebagai berikut:

1. Masyarakat membutuhkan pendampingan secara kontinyu dalam pengolahan ampas biogas.

2. Masyrakat membutuhkan informasi dan teknologi untuk pemanfaatan bio-slurry menjadi produk selain pupuk organik seperti pakan ikan, budidaya cacing dll.

3. Perlu dilakukan penyuluhan terkai peningkatan daya guna produk yang dihasilkan, sehingga mampu bersaing untuk di jual atau dikomersialkan.

\section{DAFTAR RUJUKAN}

Bigas Rumah. 2014. Pedoman Pengelolaan dan Pemanfatan Bio-Slurry. Yayasan Rumah Energi. Indonesia.

Depdagri. 2008. Pemanfaatan Kotoran Ternak untuk Biogas. Jakarta: Direktorat pembinaan Masyarakat Desa, Depdagri

Sputro, DD. 2014. Pengellaan Limbah Peternakan sapi untuk Meningkatkan Kapasitas Produksi pada Kelompok 